\title{
Glucocorticoid treatment in ileal Crohn's disease: relief of symptoms but not of endoscopically viewed inflammation
}

\author{
G Olaison, R Sjödahl, C Tagesson
}

\begin{abstract}
The effect of prednisolone (20-30 $\mathrm{mg}$ daily for six to nine weeks) was studied in eight patients with Crohn's disease and recurrent, preanastomotic ileal inflammation, in respect of symptoms, endoscopic findings and phospholipase $A_{2}$ activity in the ileal mucosa. The HarveyBradshaw Crohn's disease activity index improved significantly, mainly because of reduced frequency of loose stools and diminution of abdominal pain. Endoscopy revealed no corresponding decrease in ileal inflammation, which in all cases persisted after treatment. The phospholipase $A_{2}$ activity in the ileal mucosa was not altered by prednisolone. In two of three patients with concomitant colitits colonic inflammation improved. The study confirmed earlier reports of good symptomatic relief from glucocorticoid treatment in Crohn's disease of the small bowel, but endoscopy suggests that this improvement was not the result of resolution of small intestinal mucosal inflammation.
\end{abstract}

Although Crohn's disease has been recognised for about 50 years, its aetiology remains obscure and the inflammation inducing mechanisms are poorly understood. Phospholipase $A_{2}$ is implicated as a major contributor to inflammatory processes,' and has attracted much attention because of its ability to produce substrate for the generation of various inflammatory lipid mediators. Raised intestinal contents of prostaglandins and leucotrienes have been reported in Crohn's disease ${ }^{23}$ In line with these findings, we reported increased activity of phospholipase $\mathbf{A}_{2}$ in the ileal mucosa of patients with ileocaecal Crohn's disease, suggesting a role for this enzyme in the development of the inflammatory process. ${ }^{45}$ Glucocorticoids are considered to be inhibitors of phospholipase $A_{2}$ activity and are among the few drugs with documented effect on Crohn's disease of the small intestine. ${ }^{67}$ These steroids have been stated to exert their antiinflammatory action by inducing synthesis of a phospholipase $\mathrm{A}_{2}$-inhibiting protein. ${ }^{8-13}$

In ulcerative colitis prednisolone was found to induce remission of symptoms concomitantly with reduction of endoscopically viewed colonic inflammation. " Reports on the effect in Crohn's colitis are mainly anecdotal, but steroids appear to be beneficial in some cases. ${ }^{14}$ is Their effect on endoscopically visualised inflammation of the small bowel in Crohn's disease does not appear in the literature. Nor have we found any report concerning possible influence on the activity of mucosal phospholipase $A_{2}$.
Fibreoptic gastrointestinal endoscopy offers unique opportunities for the study of the ileal mucosa in Crohn's disease in vivo and for assessing the effects of different treatments. Mucosal biopsy can also be performed. We have studied the effects of prednisolone treatment in eight patients with Crohn's disease. All had previously undergone resection and had recurrent preanastomotic ileal inflammation. The patients were assessed before, and also six to nine weeks after medication in regard to symptoms, activity of phospholipase $A_{2}$ and endoscopic appearance of the preanastomotic ileal mucosa.

\section{Methods}

\section{PATIENTS}

Eight patients with Crohn's disease were studied aged 20-61 years (mean 43). Ileocaecal resection with anastomosis of ileum to ascending colon had previously been performed in six cases and colectomy with ileorectal anastomosis (for Crohn's colitis) in two. Ileocolonoscopy in all cases showed recurrent inflammation located preanastomotically in the neoterminal ileum. Three patients had at endoscopy concomitant colitis. Radiographic investigations before the study revealed no additional Crohn's lesions in the small intestine. The diagnosis of Crohn's disease was based on classic radiographic findings and the Morson criteria for histopathology of the previously resected tissue. ${ }^{16}$

\section{ENDOSCOPY}

Ileocolonoscopy was performed by one of the authors (GO), using an Olympus CR-101 or CFIBW colonoscope. The rectum, the remaining colon, the ileocolic or ileorectal anastomosis and, when possible, the distal part of the neoterminal ileum were inspected. In reporting the observations, $1.5 \mathrm{~cm}$ of the neoterminal ileum from the junction of the ileal and colonic mucosa is referred to as the 'anastomosis' and the ileum proximal thereto as the 'ileum'. The presence of oedema, erythema, ulcers and stricture was assessed. Ulcers were denoted as aphthous, width less than $4 \mathrm{~mm}$ or width $4 \mathrm{~mm}$ or more. Strictures were classified as 4-8 $\mathrm{mm}$ or less than 4 $\mathrm{mm}$. In assessing the width of anastomoses and the size of ulcers, an open biopsy forceps (width $8 \mathrm{~mm}$ ) was used for comparison. Ulcer size was measured at the largest diameter, and no attempt was made to quantify depth of ulcers. Erythema was assessed by comparing different parts of the intestine. Oedema was subjectively graded by the investigator.

\author{
Correspondence to: Gunnar \\ Olaison, MD, Dept of \\ Surgery, University Hospital \\ Accepted for publication \\ 13 June 1989 \\ Unköping Hospital \\ G Olaison \\ R Siödah \\ C Tagesson*
}


Biopsy specimens for enzyme analysis were taken from the neoterminal ileum $1-3 \mathrm{~cm}$ above the ileocolic anastomosis. To confirm correct visualisation of the site of anastomosis, specimens for light microscopy were taken immediately above and below the mucosal join.

\section{STUDY DESIGN}

Before the study all patients underwent thorough clinical examination and ileocolonoscopy, when mucosal biopsies were made for enzyme analysis. The activity of Crohn's disease was assessed according to the Crohn's disease activity index proposed by Harvey and Bradshaw ${ }^{17}$ (Table I), based only on symptoms. Values of 4-7 were classified as moderately severe, and higher figures as severe.

Glucocorticoid (prednisolone) medication was begun with $30 \mathrm{mg}$ daily for two weeks, followed by $25 \mathrm{mg} /$ day for two weeks, and thereafter 20 $\mathrm{mg} /$ day. After six to nine weeks, while still on treatment, the patients were re-examined.

\section{PHOSPHOLIPASE A, ANALYSIS}

The biopsy specimens were frozen at $-70^{\circ} \mathrm{C}$ until analysis. They were then thawed, weighed, and disintegrated in a Dounce homogeniser, using $0.15 \mathrm{~mol} \mathrm{NaCl}$ as homogenising medium. Phospholipase $\mathrm{A}_{2}$ activity was assayed using radiolabelled Escherichia coli as described previously. ${ }^{18}$ The reaction mixture (final volume 450 $\mu \mathrm{l})$ contained radiolabelled Escherichia coli $\left(10^{4}\right.$ cpm), $70 \mathrm{mmol}$ Tris- $\mathrm{HCl}$ buffer, $\mathrm{pH} \mathrm{6.0,2} \mathrm{mmol}$ $\mathrm{CaCl}_{2}$ and mucosal cells corresponding to $10 \mu \mathrm{g}$ protein. The mixture was incubated at $37^{\circ} \mathrm{C}$ for 90 minutes and the reaction was stopped by adding $2 \mathrm{ml}$ cold $0 \cdot 15 \mathrm{~mol} \mathrm{NaCl}$ with $1 \%$ bovine serum albumin.

The suspension was then passed through an $0.45 \mu \mathrm{m}$ millipore filter (Millex SFHA $025 \mathrm{BO}$, Millipore, V Frölunda, Sweden), and the radioactivity in the filtrate was counted and expressed in percentage of total radioactivity. One unit of enzyme activity was defined as liberation of $1 \%$ of the total radioactivity into the millipore filtrate.

STATISTICAL ANALYSIS

All values are expressed as means \pm standard deviation (SD). Two-tailed Wilcoxon's test for

TABLE I Scores for the Harvey-Bradshaw disease activity index of severity of Crohn's disease

\begin{tabular}{ll}
\hline Criteria & Scores \\
\hline A General wellbeing & $\begin{array}{l}0=\text { =ery well } \\
1=\text { slightly below par } \\
2=\text { poor } \\
3=\text { terrible } \\
0=\text { none } \\
1=\text { mild } \\
2=\text { moderately severe } \\
3=\text { severe } \\
4=\text { terrible }\end{array}$ \\
B Abdominal pain & $\begin{array}{l}0=\text { none } \\
1=\text { dubious }\end{array}$ \\
$\begin{array}{ll}\text { C Number of loose stools/day } & =\text { definite } \\
\text { D Abdominal mass } & 3=\text { definite and tender } \\
& \text { per item }\end{array}$ \\
$\begin{array}{ll}\text { E Complications: Arthralgia, uveitis, } \\
\text { erythema nodosum, aphthous ulcers, } \\
\text { pyoderma gangrenosum, anal fissure, } \\
\text { new fistula, abscess }\end{array}$ & \\
\hline
\end{tabular}

TABLE II Effects of longterm prednisolone treatment on symptoms and phospholipase $A_{2}$ activity of the ileal mucosa in eight cases of Crohn's disease (means $(S D)$

\begin{tabular}{|c|c|c|c|}
\hline Studies factors & $\begin{array}{l}\text { Before } \\
\text { treatment }\end{array}$ & $\begin{array}{l}\text { After } \\
\text { treatment }\end{array}$ & $\begin{array}{l}\text { Significance } \\
\text { of difference } \\
\text { (p-values) }\end{array}$ \\
\hline \multirow{3}{*}{$\begin{array}{l}\text { Disease activity index } \\
\text { (see Table I) } \\
\text { Loose stools/day } \\
\text { Abdominal pain } \\
\text { (see Table I) } \\
\text { Phospholipase } \mathrm{A}_{2} \text { activity } \\
\text { (units) }\end{array}$} & $\begin{array}{r}10 \cdot 9(4 \cdot 1) \\
7 \cdot 8(3 \cdot 2)\end{array}$ & $\begin{array}{l}3.6(1.6) \\
2.9(1.5)\end{array}$ & $\begin{array}{l}<0.01 \\
<0.02\end{array}$ \\
\hline & $1 \cdot 6(1 \cdot 0)$ & $.0 .5(1 \cdot 0)$ & $>0.05$ \\
\hline & $33.0(6 \cdot 6)$ & $32 \cdot 6(4 \cdot 5)$ & $>0.05$ \\
\hline
\end{tabular}

paired comparison was used, and $\mathrm{p}<0.05$ was considered statistically significant. The study was approved by the local Committee on Ethics.

\section{Results}

Glucocorticoid treatment had good subjective effect in all eight patients, with significant $(\mathrm{p}<0.01)$ improvement of symptoms according to the Harvey-Bradshaw activity index (Table II). Clinical remission occurred in two of the three patients with moderately severe symptoms at the start of treatment. The other five patients had severe symptoms, which could be reclassified as moderate in three and remitted in two. Reduction of the symptom index was mainly the result of significantly fewer $(p<0.02)$ loose stools in all eight patients. Of the seven patients who reported abdominal pain, five had improved after the treatment.

Pretreatment endoscopy revealed inflammatory changes in the anastomotic area in all eight patients (Table III). In all the patients without generalised colitis-proctitis, the anastomotic recurrence was located on the ileal side of the anastomosis. Ulcers rarely bridge the mucosal join over to the colonic side. Erythema was strictly confined to the ileal side of the anastomosis.

Post treatment endoscopy showed improvement of the inflammatory state of the ileum in two patients (disappearance of erythema or aphthous ulcers). At the anastomosis the inflammation generally was more pronounced with ulcers in seven cases and stricture in four. In one case a tight stricture widened to more than $4 \mathrm{~mm}$ (diminution of ulcers) and another deteriorated from more to less than $4 \mathrm{~mm}$ (diminution of ulcer but narrowing of the anastomosis, probably cicatricial). Slight endoscopic improvement of anastomotic inflammation - reduction of ulcer size and of oedema - was observed in five other patients, but was insufficient to change the classification according to ulcer size. In two patients whose first endoscopy showed extensive coloproctitis there was complete healing after prednisolone treatment.

No correlation was found between presence of abdominal pain and anastomotic stricture or between relief of pain and regression of such stricture. Five of the seven patients with abdominal pain reported improvement after prednisolone treatment. Three of the five had no stricture and two had unchanged stricture. Of the two patients with unchanged abdominal pain, one had reduction of stricture.

The mucosal phospholipase $A_{2}$ activity in the 
TABLE III Effects of longterm prednisolone treatment on endoscopic findings in eight cases of Crohn's disease with previous bowel resection and recurrent anastomotic inflammation

\begin{tabular}{|c|c|c|c|c|c|c|}
\hline \multirow[b]{2}{*}{ Endoscopic lesions } & \multicolumn{2}{|l|}{ Ileum } & \multicolumn{2}{|c|}{ Anastomosis } & \multicolumn{2}{|l|}{ Colon } \\
\hline & $\begin{array}{l}\text { Before } \\
\text { predni- } \\
\text { solone }\end{array}$ & $\begin{array}{l}\text { After } \\
\text { predni- } \\
\text { solone }\end{array}$ & $\begin{array}{l}\text { Before } \\
\text { predni- } \\
\text { solone }\end{array}$ & $\begin{array}{l}\text { After } \\
\text { predni- } \\
\text { solone }\end{array}$ & $\begin{array}{l}\text { Before } \\
\text { predni- } \\
\text { solone }\end{array}$ & $\begin{array}{l}\text { After } \\
\text { Predni- } \\
\text { solone }\end{array}$ \\
\hline Erytema present & 6 & 6 & 8 & 8 & 3 & 1 \\
\hline Erytema absent & - & 1 & - & - & 5 & 7 \\
\hline Not visualised & 2 & 1 & - & - & - & - \\
\hline No ulceration & - & 2 & - & - & 5 & 7 \\
\hline Aphtous ulceration & 4 & 3 & 1 & 1 & 1 & 1 \\
\hline Uĺcers < $4 \mathrm{~mm}$ & 2 & 2 & 2 & 2 & 2 & - \\
\hline Ulcers $\geqslant 4 \mathrm{~mm}$ & - & - & 5 & 5 & - & - \\
\hline Not visualised & 2 & 1 & - & - & - & - \\
\hline Stricture absent & 6 & 7 & 4 & 4 & - & - \\
\hline Stricture 4-8 mm & - & - & 2 & 2 & - & - \\
\hline Stricture $<4 \mathrm{~mm}$ & - & - & 2 & 2 & - & - \\
\hline Not visualised & 2 & 1 & - & - & - & - \\
\hline
\end{tabular}

neoterminal ileum was almost unchanged after prednisolone treatment (Table II).

\section{Discussion}

As in previous investigations, glucocorticoid treatment greatly improved the patients' symptoms, mainly the diarrhoea and abdominal pain (Table II). This improvement was accompanied by only a minor reduction of ileal and anastomotic mucosal inflammation, and all patients still had inflammation of the small bowel at the end of the treatment period. The lack of correlation between endoscopic findings and lessening of diarrhoea after treatment implies that mucosal inflammation of the small bowel was not the only cause of the diarrhoea. It cannot be excluded, however, that improvement of minor inflammation of the small bowel, proximal to the part available for endoscopy, was responsible for amelioration of the diarrhoea, and in two cases with reduction of colitis, colonic inflammation probably contributed to the diarrhoea.

Increased intestinal synthesis of prostaglandins has previously been reported to accompany intestinal inflammation, ${ }^{11} 1920$ and can cause secretory diarrhoea by impairment of water absorption and secretion of mucus. ${ }^{21}$ Reduction of diarrhoea might therefore result from glucocorticoid induced impairment of prostaglandin synthesis, also previously observed in inflammatory bowel disease. ${ }^{11} 1920$

Abdominal pain in some patients with Crohn's disease of the small intestine is undoubtedly caused by partial obstruction arising from stenosis. In our patients, however, correlation was not found between abdominal pain and presence of anastomotic stricture or between relief of pain and regression of stricture. Inflammation in Crohn's disease is often transmural, ${ }^{16}$ but only changes of the superficial mucosa are seen at endoscopy. Possibly intestinal inflammation causes pain when it reaches the serosal surface, and the beneficial action of corticosteroid treatment on abdominal pain might be explained by reduction of such transmural inflammation.

In the two patients who had extensive coloproctitis before prednisolone treatment the colorectal mucosa healed, but the anastomotic and ileal inflammation remained unchanged. Thus prednisolone seemed to be more effective against inflammation in the large than in the small gut.
The treatment period before reinvestigation was only six to nine weeks in our cases, and it is not unlikely that more extensive healing would have been found after longer medication. Moreover, it cannot be excluded that healing starts in areas of the gut that are too proximal or too deep in the intestinal wall for endoscopic visualisation.

The mucosal phospholipase $A_{2}$ activity in the neoterminal ileum was not inhibited by glucocorticoid medication. The implications of this observation are not clear. The unaffected phospholipase $A_{2}$ activity in biopsy specimens of superficial ileal mucosa accorded with substantially unchanged inflammation at endoscopic viewing. It seems noteworthy that our patients had chronic inflammation and were receiving longterm prednisolone, whereas experimental studies showing induction of phospholipase inhibition by glucocorticoids were short term and performed on non-human tissues. ${ }^{8912}$ Moreover recent investigations have questioned the mechanism by which glucocorticoids inhibits phospholipase $\mathrm{A}_{2}$ activity, ${ }^{22} 23$ and our data further question the phospholipase $\mathrm{A}_{2}$ inhibitory effect by glucocorticoids.

Our study thus confirmed the excellent effect of glucocorticoids on symptoms of Crohn's disease of the small intestine but this, remarkably, was not accompanied by a significant diminution of endoscopically observed small intestinal inflammation. These findings suggest that at least some of the symptoms in small bowel Crohn's disease are not caused by the mucosal endoscopically visualised inflammation, but by other, concomitant factors.

This study was aided by grants from Östergötlands County Council, The Swedish Society of Medicine, The Swedish Society of Medical Research and by grant B 88-17X-05983-06C from the Swedish Medical Research Council.

Chang J, Musser JH, McGregor H. Phospholipase A, Function and pharmacological regulation. Biochem Pharmacol tion and pharmacol

2 Sharon P, Stenson WF. Enhanced synthesis of leukotriene B by colonic mucosa in inflammatory bowel disease. Gastroby colonic mucosa in inflam

3 Zifroni A, Treves AJ, Sachar DB, Rachimilewitz D. Prostanoid synthesis by cultured intestinal epithelial and mononuclear cells in inflammatory bowel disease. Gut 1983; 24 659-64.

4 Bolin T, Heuman R Sjödahl R, Tagesson C. Decreased lysophospholipase and increased phospholipase $A_{2}$ activity in ileal mucosa from patients with Crohn's disease. Digestion 1984; 29: 55-9.

5 Olaison G, Siödahl R, Tagesson C. Increased phospholipase $A_{2}$ activity of ileal mucosa in Crohn's disease - A possible etiological factor. Digestion 1988; 41: 136-41.

6 Summers R W, Switz D M, Sessions Jr JT, et al. National cooperative Crohn's disease study: Results of drug treatment. Cooperative Crohn's disease study:

7 Malchow H, Ewe K, Brandes JW, et al. European cooperative Crohn's disease study (ECCDS): Results of treatment Gastroenterology 1984; 86: 249-66.

8 Flower RJ, Blackwell GJ. Anti-inflammatory steroids induce biosynthesis of a phospholipase $A_{2}$ inhibitor which prevent prostaglandin generation. Nature 1979; 278: 456-9.

9 Hirata F, Schiffmann E, Venkatasubramian K, Salomon D Axelrod J. A phospholipase $A_{2}$ inhibitory protein in rabbi neutrophils induced by glucocorticoids. Proc Natl Acad Sci 1980; 77: 2533-6.

10 Hawkey CJ. Evidence that prednisolone is inhibitory to the cyclooxygenase activity of human rectal mucosa. Prostacyclooxygenase activity of
glandins 1982; 23: $397-409$.

11 Lauritzen K, Laursen LS, Bukhave K, Rask-Madsen J. Effects of topical 5-aminosalicylic acid and prednisolone on prostaglandin $\mathrm{E}_{2}$ and leukotriene $\mathrm{B}_{4}$ levels determined by prostaglandin $E_{2}$ and leukotriene $B_{4}$ levels determined by equilibrium in vivo dialysis of rectum in rela

12 Blackwell GJ, Carnuccio R, Di Rosa M, Flower RJ, Parente L, Persico P. Macrocortin: A polypeptide causing the antiphospholipase effects of glucocorticoids. Nature 1980; 287

13 Flower RJ. Lipocortin and the mechanism of action of the glucocorticoids. Br $\mathcal{F}$ Pharmacol 1988; 94: 987-1015. 
14 Korelitz BI, Sommers SC. Response to drug therapy in Crohn's disease: Evaluation by rectal biopsy and mucosa cell counts. $\mathcal{F}$ Clin Gastroenterol 1984; 6 : 123-7.

15 Lorenz-Mayer H, Malchow H, Miller B, Stock H, Brandes JW. European cooperative Crohn's disease study (ECCDS): Colonoscopy. Digestion 1985; 31: 109-19.

16 Morson BC. Histopathology of Crohn's disease. Proc $R$ Soc Med 1968; 61: 79-81.

17 Harvey RF, Bradshaw JM. A simple index of Crohn's-disease activity. Lancet 1980; i: 514 .

18 Tagesson C, Sjödahl R. Studies of phospholipase $A_{2}$ activity of rat ileal mucosa. Scand f Gastoenterol 1985; 20: 25-30.

19 Rampton DS, Sladen GE, Youltern LJF. Rectal mucosa prostaglandin $E_{2}$ release and its relation to disease activity, electrical potential difference, and treatment in ulcerative colitis. Gut 1980; 21 : 591-6.

20 Smith PR, Dawson DJ, Swan CHJ. Prostaglandin synthetase activity in acute ulcerative colitis: Effects of treatment with sulphasalazine, codeine phosphate and prednisolone. Gut $1978 ; 20: 802-5$.

21 Rampton DS, Hawkey CJ. Prostaglandins and ulcerative colitis. Gut 1984; 25: 1399-413.

22 Northrup JK, Valentine-Braun KA, Johnson LK et al. Evaluation of the antiinflammatory and phospholipase-inhibitory activity of Calpactin II/Lipocortin I. F Clin Inves

23 Crompton MR, Moss SE, Crumpton MJ. Diversity in the Lipocortin/Calpactin family. Cell 1988; 55: 1-3. 